\section{Government must spend}

\section{London}

MORE manpower is urgently needed for research into the causes and effects of global warming, according to a new report from the Select Committee on Science and Technology of the House of Lords, the Upper House of the British parliament*.

At the United Nations' General Assembly on 8 November, Prime Minister Margaret Thatcher pre-empted one of their Lordships' recommendations to some extent, by announcing the establishment of a National Centre for Climate Modelling at the UK Meteorological Office in Bracknell, Berkshire. A spokesman for the Department of the Environment said that the centre would cost $£ 5.5$ million in its first year.

But some of the observations in the report could be construed as critical of the government's contribution to research funding, already projected to fall by $£ 250$ million over the next three years - a drop of 30 per cent in real terms (see Nature 342, 3; 1989). The select committee is hopeful that a recent report by the Universities' Grants Committee on the support of meteorology in British universities, and a study by the Coordinating Committee on Marine Science and Technology into the recruitment and training of oceanographers "will help promote the needs of these branches of science". But the select committee views the current shortage of expertise so seriously "that they have decided to conduct an enquiry into scientific and technical manpower in the next session of Parliament".

Several factors could be responsible for the shortage. Research into climate change is still in its infancy, and the numbers involved "have never been large", only about 200 to 300 researchers worldwide. But there is a growing recognition that expertise in fields ranging from mathematics to biology can be brought to bear on climate research, and the sudden demands could outstrip supply.

A key factor could be the failure of universities to attract new talent, combined with a demographic drop in the number of science graduates. Many postgraduate places remain unfilled, and the Committee may find that potential researchers are instead turning towards careers with more tangible rewards: this factor, long recognized, was noted by British Conservative MP and former minister Michael Heseltine, speaking at a meeting of the academic pressure group Save British Science (SBS) last Thursday.

But skill shortages are not confined to Britain, and the committee is looking at ways of fostering endogenous scientific expertise in developing countries, where the rate of increase in carbon dioxide emissions is greatest.
Despite the fact that the global warming observed so far is small and may, in any case, be part of a natural climate cycle, "insurance" policies to limit or counteract anthropogenic effects are needed now, before it is too late to do anything. Current models predict a rise in global mean temperature of between about 1.5 and 4.5 degrees Celsius by 2030 , and the Committee notes the many worldwide initiatives to limit the emission of greenhouse gases. Reductions might best be secured through a UN Climate Convention, but each country ought to act unilaterally to reduce greenhouse gas emissions "to behave, in other words, as though some kind of convention were in place".

Scientific issues form the core of the report. In particular, fuller understanding of global warming depends in turn on improved modelling and the acquisition of better data for these models to use. The committee notes the shortcomings of many climate models in current use, and the need to simulate atmosphere-ocean coupling accurately. Research on ocean circulation is thus seen as vital, and is a primary focus of activity at the Meteorological Office. Many of these objectives can be achieved at relatively modest cost, implying that any government funds devoted to climate research would be well spent.

For example, the Science Vote should supply the additional $£ 9.1$ million requested by the Natural Environment Research Council (NERC), the balance required to meet the costs to the United Kingdom of $£ 33.5$ million for participation in the 7year World Ocean Circulation Experiment (WOCE). And Britain should participate in the Global Energy and Water Cycles Experiment (GEWEX), a proposal by the World Climate Research Programme (WCRP) to place a lidar on a polar platform satellite in the late 1990s. A space initiative "of particular significance" will be the European Space Agency's ERS-1 oceanographic satellite, due for launch in 1991.

The UK should "make a commitment now" to the proposal for ERS-2, the successor to ERS-1, at a cost of about $£ 50$ million over five years.

These funds should not be diverted from existing monitoring facilities: "because the global observing system has been in existence for a long time," the report notes, "there is a tendency to assume that its future is assured. However, there is evidence that it is becoming increasingly fragile and subject, even in relatively prosperous countries, to government economies".

Henry Gee

${ }^{*}$ Greenhouse Effect. 6th Report from the House of Lords' Select Committee on Science and Technology. (London: HMSO) 69pp. Price $£ 7 \cdot 20$ net.

\section{Dangers for higher education}

\section{Paris}

In the draft of a report due to be published at the end of this year*, the education committee of the Organisation for Economic Co-operation and Development (OECD) finds that changes in the ways in which higher education is financed could have unsettling long-term consequences for universities.

Financial stringency, says the report's author, Professor Gareth Williams of the University of London Institute of Education, led most OECD governments to look at ways to reduce public spending on higher education between 1970 and the mid1980s. In some countries new, nongovernmental sources of funding have helped, but only Finland and France expect to see an increase in public expenditure on higher education in the forseeable future.

The report expresses some concern at potentially unwelcome side-effects of an interest in "market" approaches to funding, where universities adapt the courses they offer to the needs of the private sector, in return for non-government finance. Already increasing in the United States and Britain, under this type of arrangement the public sector remains responsible for noncommercial research, including basic science.

But if, in times of cut-backs, public funds are used entirely to support basic teaching and research, says the report, there is a danger that private sponsors will become the only source of finance for innovation.

A major shift towards this kind of funding would mean increasing numbers of staff on short-term contracts and, consequently, a greater separation between teaching and research. But, says the report, there are, in any case, "growing doubts" about the need for research and teaching to be linked within universities and it anticipates a tendency for large-scale scientific research to be carried out in specialized institutions.

The report also says that it is appropriate for universities to derive an important part of their revenue from student fees, as is the case in Britain. But this is a separate issue to that of subsidies to students. The OECD committee anticipates an increase in the use of loans, especially for courses beyond first degree, but expects that repayment of 20 per cent of fees by graduates "probably sets an upper limit to what is likely to be seen as appropriate in many countries".

The principal problem for higher education in the future, concludes the report, will be the incompatibility between increasing financial selectivity and the fundamental need for diversity in the kinds of higher education institution and courses available.

Peter Coles

A draft of the report, Changing Patterns of Finance in Higher Education, was recently discussed at a meeting of vicechancellors and legislators in Barcelona, Spain. 